\title{
Market Capitalization- Sustainability Practices aße Measurement of Private Commercial Banks of Research House Bangladesh
}

\author{
Nasreen Sultana*, Afroja Akter \\ Senior Lecturer, FBA, Eastern University, Dhaka, BANGLADESH \\ *E-mail for correspondence: nasreensultana@easternuni.edu.bd
}

Received: Dec 03, 2016;

Accepted: Mar 31, 2017;

Published: June 03, 2017

Source of Support: Nil

No Conflict of Interest: Declared

\begin{abstract}
The study investigates the sustainability practices of the private commercial banks of Bangladesh to consider these as measurement of the market capitalization of the same. In the research 30, private commercial banks have been taken into consideration where it is found that market capitalization is not wholly dependent on the issue of sustainability and there is no long run relationship between market capitalization and sustainability issues which could have an impact on the market capitalization or any direction of the market capitalization. Rather Granger Causality result shows that market capitalization could have an impact on the sustainability issues of the banks. The inclusion of some other explanatory variables in the model could deduce a better conclusion.
\end{abstract}

Keywords: Market Capitalization, Sustainability Practices, Private Commercial Bank, Bangladesh

\section{INTRODUCTION}

Sustainable development (SD) is increasingly measured to be a dynamic approach to progress. Due to demands from international buyers (Belal \& Owen, 2007), and enticement of national regulators (Khan et al, 2011), organizations have to focus on social \& environmental performances. There is also an urge for maintaining internal legitimacy (Momin \& Parker, 2013) along with corporate governance elements (Khan et al., 2014) in organization.

In this regard, calls have also been made from external stakeholders to heighten firms' initiatives on corporate sustainability reporting (Sheikh \& Beise-Zee, 2011). Sustainable development at an organizational level is described using a 'triple bottom line' that divides performance into economic, environmental and social dimensions (Topfer K., 2000). Sustainability reporting practices are now well established in the banking sector of Bangladesh. At present banks are reporting their sustainability practices through three dimensions as mentioned. This study is an effort to identify at what extent market capitalization or market perception of the conventional private commercial banks in Bangladesh is being influenced by the respective banks' economic value addition, expenditure on social and environmental dimension as well as their financial performance.

\section{ReView of Past Studies}

With the detection of the link between economic development and environmental filth and pollution in the emerging environmental awareness of the 1960s the heredity of the sustainable development concept was found. This development provided a new understanding of the factors contributing to the world's problems to the replacement of the optimism about the creation of a modern technological utopia. Nowadays the concept of SD has broadened its outlook, with more importance now being put also on the social facet (European Commission, 2002).

Today sustainable development is seen as a participatory process. This idea embodied to Principle 10 of the Rio Declaration on Environment and Development. According to that, participation of concerned citizens handles the environmental issues best. Involvement of stakeholders is necessary to know what \& how to give importance in creating a sustainable development (Bradley Guy and Kibert, 1998). The common understanding of SD compromise two dimensions: the notion of progress (to make better) and sustainability (to keep going). SD is the balancing between environmental, economic and social aspects of development (Goodland and Daly, 1996). 
Sustainability topics are persuading the success of companies more than ever. Sustainability has become a driver for both risks and opportunities in business. Strategic management and information management are thus confronted to take into account sustainability information. (Schaltegger, \& Burritt 2010). Modern enterprises use sustainability performance assessment for both exterior and interior reasons because the use of performance indicators can improve the effectiveness of the management.

Towards the sustainable exercise and management of economic, social, institutional and environmental resources a Sustainable Development Indicator (SDI) can generally be understood as a quantitative tool that analyses changes while evaluating and corresponding progress. Though, frequent use of quantifiable indicators, the choice among quantitative and qualitative indicators depends mainly on the purpose (Gallopin 1997) that are used to measure sustainability. Understanding the economic, social and environmental aspects of society together and the linkages between them are the solution to develop sustainable indicators.

The best approach for identification sustainability performance indicators is the combination of both quantifiable (quantitative) and nonquantifiable (qualitative) methods (Diakaki C., Grigoroudis E., Stabouli M., 2006). It is challenging to manage sustainability holistically as it requires a sound management framework that incorporates environmental and social performance along with business performance (Schaltegger and Wagner, 2006; Epstein and Roy, 2003).

According to Schaltegger and Wagner (2006), sustainability performance incorporates all performance dimension of a company along with all drivers of corporate sustainability. Guidelines for ensuring sustainability reporting provided through the Global Reporting Initiative (GRI) by establishing core economic, social and environmental indicators of corporate activity on impact of several environmental, social and economic corporate activities. This sort of reporting is a valuable tool for decision-making at the different level of management.

Along with GRI, World Business Council for Sustainable Development (WBCSD) in 2000 developed the ecoefficiency assessment to be used as tools for performance evaluation by dividing indicators into general indicators suitable for all activities and activity specific indicators where WBCSD also explained the process of preparing an eco-efficiency report. Figge et. al. (2002) suggested socioeconomic indicators which can be used to complete the aspects of sustainability. Moreover two attributes, the societal performance of the corporations and theoretical discussion of measuring environmental and social performance, CSR or corporate citizenship, are the research findings of 1980s (Schaltegger and Wagner, 2006).
Although banks and other financial institutions do not directly involved in activities detrimental to the environment, they do relate to the natural environment through their lending activities to borrowers that harm the natural environment (Sarokin \& Schulkin, 1991; Simpson \& Kohers, 2002). Banks accountability and responsibility towards the society and environments have therefore gained overriding importance in recent decades (Campbell \& Slack, 2011). Indeed, adopting sustainable business practices for banks is necessary since it enables them to build the corporate reputation, lowering employees' turnover, above all ensuring long-term social and environmental development as a whole (Roca \& Searcy, 2012). Given that the external environment poses threats and risks to banks, engaging banking operation in a sustainable manner offer benefits for them as well (Thompson, 1998a; 1998b). Specifically, banks can avoid experiencing three types of risks such as direct risk, indirect risk, and reputational risk. Likewise, working as a partner coupled with inspiring borrowers to implement sustainability practices have potentials for banks to reduce damaging practices across the banks' supply chain that could otherwise have adverse social, environmental impacts for banking institutions themselves (Thompson, 1998a; Halabi et al., 2006).

Numerous banks from different countries around the globe participate in the United Nations Environment Program on Environment and Sustainable Development (UNEP, 1992). Similarly, there emerged recent trends in the financial sectors to comply the 'Equator Principles,' which vitalize private lenders to consider both social and environmental impact of funding projects (Missbach, 2004). Capitalizing the issues of sustainability reporting as paramount important for the industry, the GRI has also offered financial sectors disclosures requirement applicable only to the banking arena (Khan et al., 2011). As a matter of fact, sustainability reporting is a medium that enables stakeholders to evaluate and understand how, and to what extent, decision makers of banks execute their responsibilities not only towards fund providers but also towards the society and environment as a whole.

Financial institutions do not face the direct risk of sustainability. To adequately deal with sustainability risks, banks need to take steps which go beyond their direct, short-term self-interest. Living up to the expectations of society with regard to the role of banks and linked reputational risks can be a motivation to take these steps. Increasingly, the financial sector is acknowledging that through its financing activities it runs the risk of becoming involved in violations of human rights, severe damage to the environment or other negative sustainability impacts. There are however two essentially different opinions about the effects of voluntary environmental and social measures on economic success. On the one hand, there is the idea that environmental and social activities that go beyond 
complying with the law only cause additional costs and thus conflict with the goal of economic success (e.g. Bhimani and Soonwalla 2005 discuss a continuum of effects). This view assumes that every environmental and social activity reduces economic success. The contrary position is that there is a positive relationship in which business activities advancing environmental and social objectives also increase business success. Without going into the reasons for these two contrasting viewpoints (Lankoski 2000; Schaltegger and Wagner 2006), these examples show that there are activities illustrating both sides and that the relationship between environmental and social engagement (e.g. Griffin and Mahon 1997) and business success will be specific to a given company and will probably be found along a spectrum between these two extreme views. It is important to note that when making a "business case" for corporate sustainability the sheer number of sustainability activities is less important than how sustainability management is organized. Depending on the organization of management, voluntary environmental and social activities will have either a positive or a negative effect on business success. This raises the question about the specific approaches needed to develop a business case for corporate sustainability and with the help of management control support it.

World Business Council (WBC) for Sustainable Development has developed the business case for sustainability in the financial sector by taking into account social and environmental aspects, minimizing investors' risk. The aim of such business case development is to improving the bottom line, creating long-term value and growing demand for more responsible corporate behavior creates business opportunities. An increasing number of enterprises use the internationally acknowledged performance evaluation systems, but many firms use their own sets of performance indicators or performance evaluation methodologies. According to Bossel, 1999, Bell and Morse, 2003, the term indicator has a certain technical feel to it also some characteristics like indicator must be specific, measurable, pedagogical, sensitive, reliable, based on accessible data, cost-effective, relevant and usable. Again according to Staniškis \& Arbačiauskas (2009), some important requirements for sustainability performance indicators should be fulfilled, and these include comparability/measurability, meaningfulness, integrity, continuity, clarity, and efficiency.

During the 1990s, many organizations sought to achieve sustainability by generating 'initiative fatigue' (Buchanan et.al., 1999; Morgan, 2001; Buchanan et.al., 2005). Companies are requiring a shift in mind-set and practical initiatives to amalgamate stakeholder management for handling the prospect of an evolutionary soar to sustainable value (Laszlo, 2003). The implementation process of stakeholder management practices and its proper governance have favorable influence on the long- term performance and status of companies (Post et al., 2002).

CSR creates a more holistic image of the complexity of sustainable development by creating balance among three issues like economic, social and environmental as a sustainability concept (Elkington, 1998; Enquist et.al., 2006). Furthermore, presupposing the social expectations of corporate environmental performance are continuously rising, environmental efficiency is becoming a vibrant strategy (DeSimone and Popoff, 2000).

Bangladesh also implemented the CSR practices and standards for enduring in the environment of global competitiveness and demand (Alimullah, 2006). Though CSR activities are an important elements for sustainable development, these are not that much noteworthy in compare to the profit margins of relevant PCBs (Hassan, 2013).

Sultana \& Akter (2015) found some factors of sustainability for the banking sector in Bangladesh and the most important factors are environmental \& social responsibilities, customer gratification, financial performance, political \& economic factor, accountability \& transparency, sensible competitiveness, operational efficiency, employee contentment, and legal factors which influence the sustainability.

\section{MetHodology OF THE STUdY}

The study is an inferential and quantitative research in nature. The research examines the impact of sustainability practices from the three pillar concepts including the financial dimension of selected commercial banks of Bangladesh on their market capitalization or the value of individual. Here, secondary data is collected from the annual reports of the selected banks and DSE website over the period of 2008-2014. As the new banks are too new for getting available data, the study area is confined to banks those existed till 2007.

There are 30 listed banks (conventional \& Islamic) in the DSE to which the researchers have access to their data although their actual number is, as per the Bangladesh Bank database, nearly 38. Out of this total, 8 did not have the information for the required period to get their information regarding contribution towards stakeholders. Therefore the sample size for the study reduced to 30 . Usually, this number does not violate the general rule of thumb that for the generalization, a ratio of a number of observations to the number of variables should never fall below 5:1(Hair et al., 2006). Moreover, Nyamsogoro (2010) states that, although the minimum is $5: 1$, to be representative "the desired level is between 15 to 20 observations for each independent variable."

Here three independent variables- financial, economic, and social \& environmental sustainability were used with a response variable or dependent variable-market capitalization for conducting multiple regression analysis. 
For measuring economic sustainability, economic value added by the companies in several aspects were used such as contribution to government in the form of tax and deferred tax, local taxes, VAT and excise duties; contribution to employee in the type of salary, benevolent fund, employee welfare fund and gratuity fund; contribution to shareholders in the form of retained earnings, stock dividend and cash dividend, contribution to firm itself for growth and expansion in the type of depreciation, statutory reserve, special reserve, general and other reserve. Market capitalization was used here for sustainability performance measurement. For developing a sustainability indicator framework, three pillar taxonomy, is being widely utilized by the researchers among the various taxonomies in the field of sustainability. For this study the following structural model was used to estimate the association between logtransformed variables.

$\ln Y_{i t}=\beta_{0}+\beta_{1} \ln X_{1 i, t}+\beta_{2} \ln X_{2 i, t}+\beta_{3} \ln X_{3 i, t}+\varepsilon_{i, t}$
Where,

$\ln \mathrm{Y}=$ Natural $\log$ of Market Capitalization, $\ln \mathrm{X}_{1}=$ Natural $\log$ of Net Income,

$\ln X_{2}=$ Natural log of Economic value added,

$\ln X_{3}=$ Natural $\log$ of Expenditure in social \& environmental dimension,

$\beta 0, \beta 1, \beta 2$, and $\beta 3$, are the parameters known as the intercept and slope coefficient and $\varepsilon$ is the typical random disturbance term. Data are processed through Microsoft Excel and E-Views 8.0 software. Augmented Dickey and Fuller test (ADF test) were done to check for the nonstationarity of the data. The Least Square (LS) Regression as well as Cointegration test is conducted to see long run relationship of the variables. Also, Granger Causality Test is conducted with the help of E-Views 8.

\section{ANALYSIS AND FINDINGS}

The data was mined and gathered in the MS Excel for analyzing. The investigation result is portrayed here.

Graph 1: selected commercial banks' market capitalization about economic value added, net income and corporate social responsibility \& environment from the year 2008 to 2014.

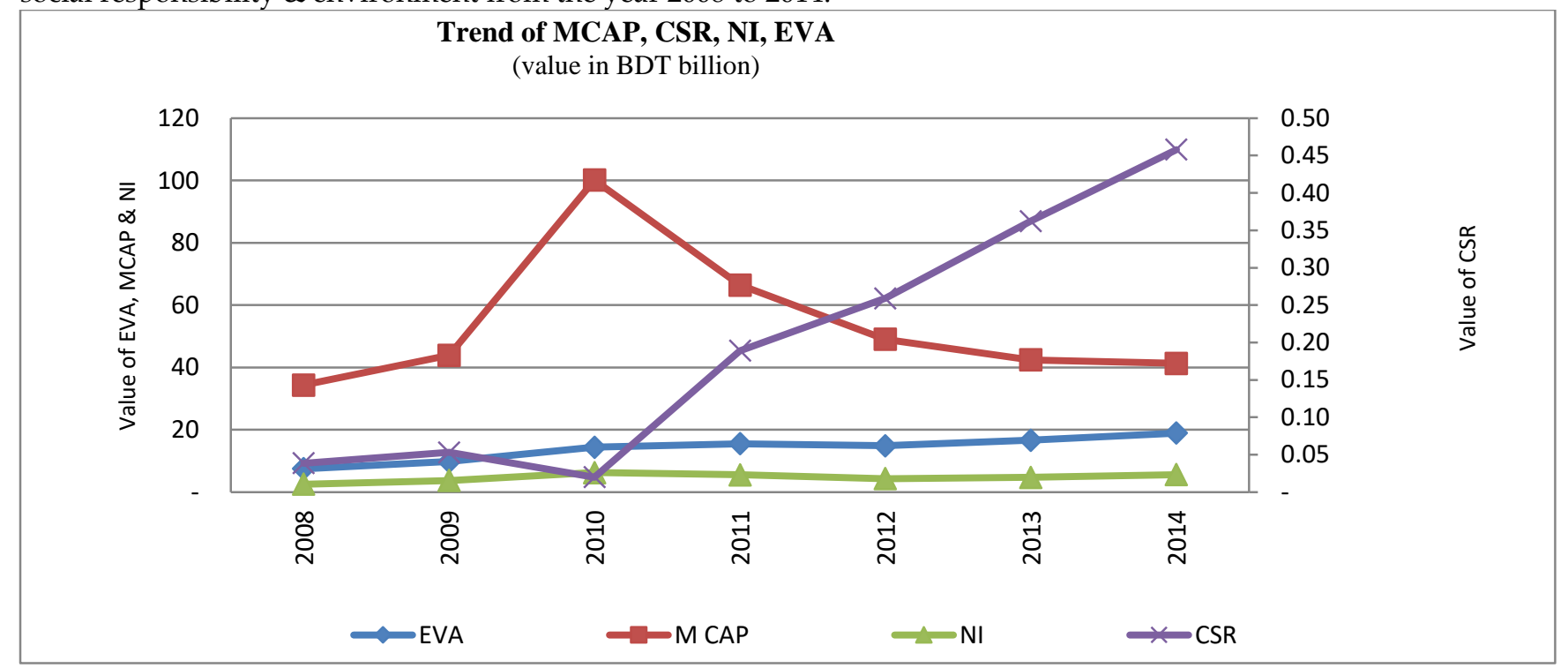

The above graph represents the selected commercial banks' market capitalization about contribution to stakeholders, net income and corporate social responsibility \& environment from the year 2008 to 2014. The market capitalization is a peak in the year 2010 significantly than the other year which is the year of a turmoil of stock market. From the year 2008 to 2010 it has an increasing trend but, after 2010 it shows a decreasing pattern.

A different picture is portraying in a case of economic value added and expenditure on corporate social responsibility \& environmental issues from the year 2008 to 2014. The line of banks' EVAs increased with a bit decreasing mode in 2012. It signifies that banks' involvement with its stakeholders increasing which may lead towards sustainability. The line of banks' corporate social responsibility \& environment had an increasing trend from 2008 to 2011, and after a slight slide in 2012, it had been on the uptrend. The line of banks' net income signifies almost similar pattern as market capitalization which increased from 2008 to 2010 . It seems that like other industries, the banking sector was also affected by the stock market crash which is apparent in the above graph. After 2010, aggregated net income of the banking sector decreased, and this decreasing trend continued till 2012. And it shows an escalating pattern for 2013 and 2014 which is reverse to market capitalization. This difference may be a sign of the late reflection of profitability trend of the banking sector in the market capitalization though it is not always true for all banks at a time.

\section{Data Stationarity Test (Trend \& Intercept):}

For using these data for further analysis unit root test for each series have been done. 
Table 1: ADF test statistics for unit root

\begin{tabular}{|l|l|l|l|}
\hline Variables & ADF Test Statistics & & \\
\hline & Level & $\begin{array}{l}\text { First } \\
\text { Difference }\end{array}$ & $\begin{array}{l}\text { Second } \\
\text { Difference }\end{array}$ \\
\hline LMCAP & -2.892019 & -4.150549 & - \\
\hline LFS & -2.634511 & -4.828513 & - \\
\hline LSES & -11.28402 & -13.80910 & - \\
\hline LES & -1.296764 & -2.884607 & -13.04795 \\
\hline & Test Critical Value & & \\
\hline 1\% Level & -4.005809 & -4.005809 & -4.005809 \\
\hline 5\% Level & -3.433036 & -3.433036 & -3.433036 \\
\hline 10\% Level & -3.140335 & -3.140335 & -3.140335 \\
\hline
\end{tabular}

Table 1 shows the results of ADF test statistic used to check the non-stationary property of the data and to determine how many times the variable needs to be differenced to result in a stationary series. The results in Table 1 show that ADF tests fail to reject the null of nonstationary for LFS, LES and LMCAP at a level, so data is nonstationery at level. But for LSES null hypothesis can be rejected, so there is no unit root and data is stationery.

After first differencing the result shows that LMCAP, LFS \& LSES became stationary as they have no unit root at the $1 \%$ significance level and LES is nonstationery at any significance level, implying that all the variables except economic sustainability are first order integrated I(1). As economic sustainability, time series has unit root at level data and first difference data, unit root test has been done for the second difference data of the time series where the data has no unit root means data is stationary at the second difference.

The estimation of the equation by direct LS gives the following one:

Table 2: Equation

\begin{tabular}{|c|c|c|c|c|}
\hline \multicolumn{5}{|c|}{ Dependent Variable: MCAP } \\
\hline \multicolumn{5}{|c|}{ Method: Least Squares } \\
\hline \multicolumn{4}{|c|}{ Included observations: 204 after adjustments } & \\
\hline Variable & Coefficient & Std. Error & t-Statistic & Prob. \\
\hline C & 6.770491 & 1.105969 & 6.121774 & 0.0000 \\
\hline LES & 0.287150 & 0.091447 & 3.140060 & 0.0019 \\
\hline LFS & 0.488726 & 0.082396 & 5.931449 & 0.0000 \\
\hline LSES & 0.001859 & 0.006075 & 0.305982 & 0.7599 \\
\hline R-squared & 0.576907 & \multicolumn{2}{|c|}{ Mean dependent var } & 23.41986 \\
\hline Adjusted R-squared & 0.570560 & \multicolumn{2}{|c|}{ S.D. dependent var } & 0.645212 \\
\hline S.E. of regression & 0.422818 & \multicolumn{2}{|c|}{ Akaike info criterion } & 1.135662 \\
\hline Sum squared resid & 35.75498 & \multicolumn{2}{|c|}{ Schwarz criterion } & 1.200724 \\
\hline Log likelihood & -111.8376 & \multicolumn{2}{|c|}{ Hannan-Quinn criter. } & 1.161981 \\
\hline F-statistic & 90.90297 & \multicolumn{2}{|c|}{ Durbin-Watson stat } & 1.285810 \\
\hline Prob (F-statistic) & 0.000000 & & & \\
\hline
\end{tabular}

$\mathrm{LMCAP}=6.770+0.488 \mathrm{LFS}+0.0018 \mathrm{LSES}+0.287 \mathrm{LES}$

The slope coefficient of the independent variable is statistically significant at $1 \%$ level for LFS and LES and shows a positive relationship. But the independent variable, LSES, is not statistically significant. The value of adjusted R- squared explains that $57.69 \%$ of the variation of the dependent variable, market capitalization as a proxy of sustainability is due to variations in independent variables taken together namely financial sustainability (LFS), economic sustainability (LES), and social \& environmental sustainability (LSES). So R-squared cannot explain $42.31 \%$ variations of the dependent variable. It indicates low explanatory power and the possibility of other external influencing variables. However, the Rsquared above 0.2 is still large enough for reliable conclusions for panel data (Cameron, 2009 cited in Nyamsogoro, 2010). Moreover, $F=90.90297$ and $\mathrm{P}=0.000$ imply that the regression model significantly fits the data. But as all the variables LFS, LES, LSES \& LMCAP, are stationary at different level Cointegration has been done.

Table 3: Cointegration

\begin{tabular}{|c|l|l|l|}
\hline \multicolumn{2}{|c|}{ 1 Cointegrating Equation(s): } & \multicolumn{1}{c|}{ Log likelihood } & -817.7677 \\
\hline Normalized cointegrating coefficients (standard error in parentheses) \\
\hline LMCAP & LFS & LSES & LES \\
\hline 1.000000 & 0.225610 & -0.167052 & -1.372508 \\
\hline & $(0.29512)$ & $(0.02895)$ & $(0.32460)$ \\
\hline
\end{tabular}

As the variables are considered to be $\mathrm{I}(1)$, the Cointegration method is appropriate to estimate the longrun relationship between the variables. With the linear deterministic trend assumption to explore the number of cointegrating vectors, Maximal Eigenvalue and Trace statistics both are used and shown in Table 3. The Trace statistic and Maximal Eigen statistic both identified two cointegrating vectors. The result of Cointegration implies the existence of a steady long-run association ship among the variables. The normalized cointegrating coefficients show that in the long run contribution towards stakeholders has a positive impact on market capitalization. The relationship is found statistically significant at the $5 \%$ level. The result is implying that in Bangladesh, in the long run, a $1 \%$ increase in financial sustainability, a $1 \%$ increase in economic sustainability, and a $1 \%$ increase in social \& environmental sustainability contributes $.2256 \%$ decrease, $1.3725 \%$ increase contributes $0.1671 \%$ increase respectively in market capitalization of the banks.

Table 4: Granger Causality Tests

\begin{tabular}{|c|c|c|c|}
\hline \multicolumn{4}{|l|}{ Pairwise Granger Causality Tests } \\
\hline \multicolumn{3}{|l|}{ Sample: 1210} & \\
\hline \multicolumn{2}{|l|}{ Lags: 2} & & \\
\hline Null Hypothesis: & Obs & F-Statistic & Prob. \\
\hline LFS does not Granger Cause LMCAP & 202 & 0.49088 & 0.6128 \\
\hline \multicolumn{2}{|l|}{ LMCAP does not Granger Cause LFS } & 4.29801 & 0.0149 \\
\hline LES does not Granger Cause LMCAP & 208 & 0.19422 & 0.8236 \\
\hline \multicolumn{2}{|l|}{ LMCAP does not Granger Cause L ES } & 4.34131 & 0.0142 \\
\hline LSES does not Granger Cause LMCAI & 208 & 19.8971 & 1.E-08 \\
\hline \multicolumn{2}{|l|}{ LMCAP does not Granger Cause LSES } & 8.50716 & 0.0003 \\
\hline LES does not Granger Cause LFS & 202 & 0.08696 & 0.9168 \\
\hline \multicolumn{2}{|l|}{ LFS does not Granger Cause LES } & 1.08218 & 0.3409 \\
\hline LSES does not Granger Cause LFS & 202 & 3.63645 & 0.0281 \\
\hline \multicolumn{2}{|l|}{ L FS does not Granger Cause LSES } & 2.58842 & 0.0777 \\
\hline LSES does not Granger Cause LES & 208 & 4.47322 & 0.0126 \\
\hline \multicolumn{2}{|l|}{ LES does not Granger Cause LSES } & 12.2661 & 9.E-06 \\
\hline
\end{tabular}

The final step of the analysis is to test for causality between market capitalization and financial, economic, social \& environmental sustainability in the long run 
which is in Table 4. Granger-causality results suggest that the null hypotheses that LMCAP does not Granger because LFS, LES, LSES is rejected at 5\% significance level which states that there is a uni-directional causality running from market capitalization to financial sustainability, economic sustainability, and social \& environmental sustainability.

\section{CONCLUSION}

In today's Bangladesh, sustainability issue is like a buzzword. As a matter of fact, governing authority has more focus on the sustainability relevant issues as they have the supreme concentration from the global influential. This study tries to unearth the extent of financial, economic and environmental \& social sustainability issues of the existing conventional and nonconventional banks of the country and whether issues are having any influence over the market capitalization of the banks. From the study, it can be inferred that market capitalization is not wholly dependent on the subject of sustainability though that was the hypothesis for analysis at the initial stage of research. It is also found from the analysis that there is no long run relationship between market capitalization and sustainability issues (financial sustainability, economic sustainability, and environmental \& social sustainability) which could have an impact on the market capitalization or any direction of the market capitalization. Rather Granger Causality result shows that market capitalization could have the impact on the sustainability issues of the banks.

\section{FUtURE SCOPE}

The study limited its investigation by the hypothesis that the market capitalization is dependent on the financial, environmental, social and economic sustainability of the banking sector. Future study, in investigating the factors that could have the better alternative for explaining the market capitalization as well as improved indicators of the sustainability on different issues can be found out.

\section{REFERENCES}

Ahmed Sheikh, N., Wang, Z., \& Khan, S. (2013). The impact of internal attributes of corporate governance on firm performance: evidence from Pakistan. International Journal of Commerce and Management, 23(1), 38-55.

Alimullah, M.M. (2006), "Dynamics of Corporate Social Responsibility - Bangladesh Context" Journal of AIUB Bangladesh, August, Vol.3, No. 1, Pp. 13-32

Belal, A. R., \& Owen, D. L. (2007). The views of corporate managers on the current state of, and future prospects for, social reporting in Bangladesh: An engagement-based study. Accounting, Auditing \& Accountability Journal, 20(3), 472-494.

Bell, S., \& Morse, S. (2003). Learning from experience in sustainability.

Bhimani, A., \& Soonawalla, K. (2005). From conformance to performance: The corporate responsibilities continuum. Journal of Accounting and Public Policy, 24(3), $165-174$.
Bossel, H. (1999). Indicators for sustainable development: theory, method, applications (p. 138). Winnipeg: International Institute for Sustainable Development.

Bradley Guy, G., \& Kibert, C. J. (1998). Developing indicators of sustainability: US experience. Building research \& information, 26(1), 39-45.

Buchanan, D., Claydon, T., \& Doyle, M. (1999). Organisation development and change: the legacy of the nineties. Human Resource Management Journal, 9(2), 20-37.

Buchanan, D., Fitzgerald, L., Ketley, D., Gollop, R., Jones, J. L., Lamont, S. S., \& Whitby, E. (2005). No going back: A review of the literature on sustaining organizational change. International Journal of Management Reviews, 7(3), 189205.

Campbell, D., \& Slack, R. (2011). Environmental disclosure and environmental risk: Sceptical attitudes of UK sell-side bank analysts. The British Accounting Review, 43(1), 54-64.

DeSimone, L. D., \& Popoff, F. (2000). Eco-efficiency: the business link to sustainable development. MIT press.

Diakaki, C., Grigoroudis, E., \& Stabouli, M. (2006). A risk assessment approach in selecting environmental performance indicators. Management of Environmental Quality: An International Journal, 17(2), 126-139.

Elkington, J. (1998). Partnerships from cannibals with forks: The triple bottom line of 21st-century business. Environmental Quality Management, 8(1), 37-51.

Enquist, B., Johnson, M., \& Skålén, P. (2006). Adoption of corporate social responsibility-incorporating a stakeholder perspective. Qualitative Research in Accounting \& Management, 3(3), 188-207.

Epstein, M. J., \& Roy, M. J. (2003). Making the business case for sustainability. Journal of Corporate Citizenship, 9(1), 79-96.

European Commission, (2002), "Thematic Evaluation on the Contribution of the Structural Funds to Sustainable Development: A Synthesis Report", Vol. 1, Vol. 2 and Annexes, DG Regio, Brussels.

Fichter, D. Ö. K., \& Clausen, D. I. J. (1998). World Business Council for Sustainable Development-WBCSD. In Schritte zum nachhaltigen Unternehmen (pp. 302-303). Springer Berlin Heidelberg.

Figge, F., Hahn, T., Schaltegger, S., \& Wagner, M. (2002). The sustainability balanced scorecard-linking sustainability management to business strategy. Business strategy and the Environment, 11(5), 269-284.

Gallopin, G. C. (1997). Indicators and their use: information for decision-making. Scope-Scientific Committee on Problems of the Environment International Council of Scientific Unions, 58, 13-27.

Goodland, R., \& Daly, H. (1996). Environmental sustainability: universal and non-negotiable. Ecological applications, 6(4), 1002-1017.

Griffin, J. J., \& Mahon, J. F. (1997). The corporate social performance and corporate financial performance debate twenty-five years of incomparable research. Business \& Society, 36(1), 5-31.

Hair, J. F., Black, W. C., Babin, B. J., Anderson, R. E., \& Tatham, R. L. (2006). Multivariate Data Analysis Sixth Edition Pearson Education. New Jersey, 42-43. 
Halabi, A. K., Kazi, A. U., Dang, V., \& Samy, M. (2006). How the top ten stack up. Monash Business Review, 2(3), 20-24.

Hassan, M. (2013). Corporate social responsibility in the banking sector: A comparative study on some commercial banks in Bangladesh.

Initiative, G. R. (2006). Sustainability reporting guidelines, Version 3.0. GRI, Amsterdam.

Khan, H. U. Z., Azizul Islam, M., Kayeser Fatima, J., \& Ahmed, K. (2011). Corporate sustainability reporting of major commercial banks in line with GRI: Bangladesh evidence. Social responsibility journal, 7(3), 347-362.

Khan, H. U. Z., Mohobbot, A. M., \& Fatima, J. K. (2014). Determinants and Recent Development of Sustainability Reporting of Banks in Developing Countries: The Case of Bangladesh. Corporate Ownership \& Control, 11(4), 505520.

Lankoski, L. (2000). Determinants of environmental profit: An analysis of the firm-level relationship between environmental performance and economic performance. Helsinki University of Technology.

Laszlo, C. (2003). The sustainable company: How to create lasting value through social and environmental performance. Island Press.

Luo, X., \& Bhattacharya, C. B. (2006). Corporate social responsibility, customer satisfaction, and market value. Journal of marketing, 70(4), 1-18.

Missbach, A. (2004). The Equator Principles: Drawing the line for socially responsible banks? An interim review from an NGO perspective. Development, 47(3), 78-84.

Momin, M. A., \& Parker, L. D. (2013). Motivations for corporate social responsibility reporting by MNC subsidiaries in an emerging country: The case of Bangladesh. The British Accounting Review, 45(3), 215-228.

Morgan, N. (2001). How to overcome "change fatigue". Harvard Management Update, 6(7), 1-3.

Nyamsogoro, G. D. (2010). Financial sustainability of rural microfinance institutions (MFIs) in Tanzania (Doctoral dissertation, University of Greenwich).

Petros Sebhatu, S., \& Enquist, B. (2007). ISO 14001 as a driving force for sustainable development and value creation. The TQM Magazine, 19(5), 468-482.
Post, J. E., Preston, L. E., \& Sauter-Sachs, S. (2002). Redefining the corporation: Stakeholder management and organizational wealth. Stanford University Press.

Rahman, M. A., \& Kamruzzaman, M. Sustainable Development of Commercial Banks in Bangladesh.

Roca, L. C., \& Searcy, C. (2012). An analysis of indicators disclosed in corporate sustainability reports. Journal of Cleaner Production, 20(1), 103-118.

Sarokin, D., \& Schulkin, J. (1991). Environmental concerns and the business of banking. Journal of Commercial Bank Lending, 74(5), 6-19.

Schaltegger, S., \& Burritt, R. L. (2010). Sustainability accounting for companies: Catchphrase or decision support for business leaders?. Journal of World Business, 45(4), 375-384.

Schaltegger, S., \& Wagner, M. (2006). Integrative management of sustainability performance, measurement and reporting. International Journal of Accounting, Auditing and Performance Evaluation, 3(1), 1-19.

Sheikh, S. U. R., \& Beise-Zee, R. (2011). Corporate social responsibility or cause-related marketing? The role of cause specificity of CSR. Journal of Consumer Marketing, 28(1), 27-39.

Simpson, W. G., \& Kohers, T. (2002). The link between corporate social and financial performance: Evidence from the banking industry. Journal of business ethics, 35(2), 97-109.

Staniškis, J. K., \& Arbačiauskas, V. (2009). Sustainability performance indicators for industrial enterprise management. Environmental Research, Engineering and Management, 48(2), 42-50.

Sultana, N. \& Akter, A. (2015) “Factors influencing the sustainability of private commercial banks in Bangladesh", proceedings of the $13^{\text {th }}$ SAMF international conference in Colombo, Srilanka, 2015, AMDISA \& ICPM, Srilanka, pp. 170-179.

Thompson, P. (1998). Assessing the environmental risk exposure of UK banks. International Journal of Bank Marketing, 16(3), 129-139.

Thompson, P. (1998). Bank lending and the environment: policies and opportunities. International Journal of Bank Marketing, 16(6), 243-252.

Topfer, K. (2000). The triple bottom line economic, social natural capital. UN Chronicle, 36(2), 39-41. 


\section{SOCIAL SCIENCE RESEARCH NETWORK}

2171 Monroe Avenue, Suite 203, Rochester, NY 14618, USA http://www.ssrn.com/en/

AJTP Link: http://www.ssrn.com/link/American-Journal-Trade-Policy.html 